\title{
The Invention of Sacred Places and Rituals: A Comparative Study of Pilgrimage
}

\section{John Eade (Roehampton/Toronto)}

\begin{abstract}
During the last twenty years around the world there has been a rapid increase in the number of people visiting long established religious shrines as well as the creation of new sites by those operating outside the boundaries of institutional religion. This increase is intimately associated with the revival of traditional routes, the creation of new ones and the invention of new rituals (religious, spiritual and secular). To examine this process I will focus on the European region and two contrasting destinations in particular - the Catholic shrine of Lourdes, France, and the pre-Christian shrine of Avebury, England - drawing on my personal involvement in travelling to both destinations and being involved in ritual activities along the route and at the two destinations. In the discussion section of the paper I will explore the relevance of these two case studies to the analysis of power, agency and performance and the ways in which they expose (a) the role of institutions and entrepreneurs in creating rituals and sacred places and (b) the relationship between people and the domesticated landscape.
\end{abstract}

\section{Keywords}

pilgrimage, ritual, power, agency, performance, entrepreneurs, institutional religion

\section{Introduction}

Global migration has increased massively during the last thirty years. Two main types of migrant have been involved - poor migrants such as refugees and labour migrants have moved to wealthy countries and regions, i.e. the USA, Canada, W. Europe, the Middle East, S. Africa and Australasia, while citizens from these wealthy countries and regions have 
migrated globally as tourists, well paid contract workers or permanent skilled workers. Pilgrimage destinations have benefitted massively from the global expansion of the travel and tourism sector. These are not just those organised by religious institutions, such as Mecca, Amritsar, Varanasi and Lourdes but also destinations associated with alternative cults usually categorised as 'New Age', 'alternative' or 'spiritual' (see Bowman, 1996; Ivakhiv 2001; Rountree 2006; Fedele 2013), as well as with death and suffering, such as military cemeteries in Flanders and Gallipoli or the death camps in Poland (Walter 1993; Lloyd 1998; Feldman 2007) and with celebrities, such as Elvis Presley (King 1993). The intimate relationship between pilgrimage and tourism has been analysed in terms of such hybrid categories as pilgrimage tourism, tourist pilgrimage and religious tourism (see Nolan and Nolan 1989; Eade 1992; Vukonic, Bar and Cohen-Hattab 2003; Badone and Roseman 2004; CollinsKreiner 2010, 2016 ).

This expansion has involved not only long established religious pilgrimage centres but also the emergence of new religious and non-religious sites, the revival of traditional routes such as the camino to Santiago de Compostela and the invention of new routes (see Frey 1998; Sanchez y Sanchez and Hesp 2006; Steil 2017). These developments have gone hand in hand with the adaptation of traditional rituals and the invention of new ones. Analysis of pilgrimage ritual has been deeply influenced by the pioneering Image and Pilgrimage in Christian Culture (1978) written by Victor and Edith Turner who argued that ritual celebrated the temporary, liminal commonality of its participants (normative communitas). Subsequent debate focused on the contested and diverse meanings evident in such ritual (Wikan 1990; Eade and Sallnow 1991), while research has also demonstrated the manifold ways in which religious and non-religious rituals are invented and change (Abélès 1988; Grimes 1992; Karant-Nunn 1997), as well as 'the uncertain and open-ended nature of ritual practices and processes' (Stern 2012, p. 77). 
At the same time, the study of people's engagement with material culture and landscape has also expanded. Thomas Tweed, for example, has explored the dwellings and crossings involved in pilgrimage flows across landscapes to places and sacred objects by reflecting on his own positionality and engagement with religion (Tweed 2006). Pilgrimage has been interpreted as a kinetic ritual where people engage with a landscape's immanent features and aura. Such an approach can lead to an analysis of how 'mobile practices help construct apparently sacredly charged places', the 'power of place' and the 'role of landscape aesthetics in the "spiritual magnetism" of pilgrimage sites' (Maddrell et al. 2015, pp. 6-7).

This attention to mobile practices, flows and the relationship between people and places has helped pilgrimage studies to explore new avenues but careful attention still needs to be paid to the role played by power and authority in ritual invention and performance. The rituals performed by groups journeying to shrines and at the shrines themselves are typically orchestrated by leaders, such as priests or experienced laity, who draw on specialist knowledge and their ascribed or achieved status as 'experts' (Bajc 2007. Their role as leaders is very similar to that performed by tourist guides (Feldman 2007; Kormina 2010; Mesaritou, Coleman and Eade 2016) and pilgrimage journeys may involve both pastors and tour guides (see Bajc 2006, 2007). These leaders play an integral part in the global expansion of the travel and tourism industry (see Kaell 2010; Reader 2014) where the interweaving of pilgrimage and tourism has been analysed in terms of the hybrid category 'pilgrimage tourism' (Collins-Kreiner and Kliot 2000; Schramm 2004; Shuo, Ryan and Liu 2009; Lopez 2013).

To explore the role played by leadership, power and authority in ritual invention and performance I will bring together two contrasting case studies - rituals observed at the Roman Catholic shrine of Lourdes, France, and those performed during a pilgrimage to the prehistoric Avebury Ring in south-west England. 


\section{Lourdes: the invention of place, routes and rituals}

Lourdes is a small town in the foothills of the Pyrenees near the French border with Spain. Its fortunes were transformed in the aftermath of visions of Mary, the mother of Jesus, experienced by Bernadette Soubirous, a young shepherdess, at a grotto outside the town during 1858 and subsequent claims of miraculous healing associated partly with a spring which she uncovered during her séances. The Roman Catholic Church quickly moved to carve out a sanctuary around the grotto where three churches were built on the cliff overlooking the grotto and a large esplanade was laid out for the daily performance of collective rituals. The spring was channelled into private baths for those wishing to immerse themselves in 'Lourdes water' while others could take away the water by accessing the taps constructed along a wall near the grotto and the baths.

A new pilgrimage town grew up between the old town and the sanctuary, while a new route was provided through the building of a railway loop connecting Lourdes to the expanding national and European railway network. In 1871 - only thirteen years after Bernadette's visions - the first international pilgrimage group arrived from Belgium and soon afterwards the first Irish pilgrimage arrived having crossed by boat to England, by railway to Dover, ferry to Calais and then down to the margins of France. The development of a national road network enabled growing numbers of people to arrive by car or coach and after the Second World War the volume of arrivals massively increased aided by the expansion of international air transport. Between 1949 and 2008 the numbers of people arriving, mostly during the pilgrimage season between May and October, rose from approximately 2,500,000 to around $9,000,000$. The sanctuary provided a variety of ritual events to cater for this mass of visitors that ranged from celebrations performed inside the three basilicas, at the grotto and, more recently, across the river at an altar installed on the meadow to the regular 
afternoon Eucharistic or Blessed Sacrament procession, popularly known as the Blessing of the Sick ceremony, and the evening Torchlight Procession, both of which used the esplanade.

While the last two celebrations have caught the eye of many observers (see Zola 1894; Harris 1995; Kaufman 2005), pilgrimage groups also performed rituals on the way both to and from the shrine. During the train journeys groups organised by parishes, dioceses, Catholic orders and national institutions prayers were intoned while the Lourdes Hymn was joyfully sung as the main basilica standing high on the cliff overlooking the grotto came into view. Those who came by coach sometimes had the opportunity to stop at other famous shrines on the way, such as Nevers where Bernadette's body is on display (see Dahlberg 1991), Lisieux or Chartres. For the increasing number of people arriving by plane there were very few opportunities for ritual performance but once everyone had disembarked and were seated in the coaches taking them from the airport to the town there were also opportunities for the recitation of prayers and perhaps a verse of the Lourdes Hymn.

\section{The Blessed Sacrament procession: ritual, power, leadership and bodies}

My involvement with Lourdes began when I joined the Oxford Chaplaincy pilgrimage group in 1969. We stayed for a week as volunteer helpers under the command of the lay confraternity, the Hospitality of Our Lady of Lourdes, which coordinated work at the shrine, the station and airport, such as helping people in and out of trains and planes, helping with crowd control at the grotto, outside the baths and during the main events, and assisting inside the baths and hospitals. I continued to go on pilgrimage with the group until 1992 and returning again for six years in 2013. This lengthy acquaintance with Lourdes enabled me to observe the relationship between ritual, power and the senses.

To many visitors including those who popped in for the day and those who only went on pilgrimage a few times these rituals could appear to be long lasting and unchanging. 
However, they have changed significantly to reflect wider religious and social transformations. The afternoon Blessed Sacrament ceremony provides a clear illustration of both ritual stasis and change. During the 1970s when I first started to visit Lourdes on pilgrimage the ceremony followed a regular routine. It began at 4.30 p.m. and involved the Host being taken in a monstrance by a senior cleric (often a bishop or cardinal) followed by a long line of priests, doctors, members of the Hospitality, pilgrimage groups and Catholic organisations. It began near the grotto and snaked up to one of the main gates to the sanctuary and then down to the main square where the malades were assembled in rows. Shepherded by senior members of the Hospitality the priest walked in front of the lines of malades and the crowds behind them blessing them with the Host and when this was complete he stood at the foot of the steps in front of the three basilicas while the assembled throng sang the Latin hymn to Our Lady (St. Mary, mother of Jesus) - Salve Regina (Hail, Holy Queen). At the end of the ceremony the Host was taken inside one of the basilicas and placed inside a tabernacle while the participants dispersed.

This particular format was developed by Fr. Picard in 1888 to make use of the new esplanade. He had observed the procession which another priest had initiated for his pilgrimage group where he processed with the Host from the basilica to the grotto for evening benediction (Harris 1999, p. 279). The Eucharistic or Blessed Sacrament procession was popularly known as the Blessing of the Sick ceremony since the climax of the ritual for many people was the parading of the Host around the serried ranks of malade and the repeated invocation for healing by the master of ceremonies. During the late nineteenth century the procession became intimately associated with claims of miraculous healing. As Suzanne Kaufman notes, 'whereas only six of forty-two verified cures in 1888 took place during the first Procession of Blessed Sacrament, more than half of the verified cures happened there by 1894, a margin that continued for the rest of the decade' (Kaufman 2005, p. 107). 
Ruth Harris (1999) provides a description by a French woman of her cure in 1890. Mlle Benogni felt 'unable to ask for a cure until she saw the procession again two days' after she had bathed in the piscines:

... the procession was advancing slowly, coming from the grotto, where several invalids had risen on Christ's passage [referring here to the Host as Jesus's body].

Two stretcher-bearers helped me to get out of the little carriage. Jesus was coming forward, blessing and curing the souls and the bodies. A supernatural force made me walk, part the crowd and place myself behind the platform! ...Then, upright and steady ... I followed the procession, imbued with love and gratitude, for Him whose single glance had restored me to life! (quoted in Harris 1999, p. 316)

By the 1970s the association between the procession and miraculous healing had become faint. The ritual appeared to emphasise more the sacramental character of the Host rather than the ceremony's wonder-working energy (see Dahlberg 1991). The ceremony was moving, especially when the malades were blessed, but it lacked the drama of miraculous healing recorded during the late $19^{\text {th }}$ century. The change reflected the role played by the religious leadership at the shrine and their hierarchical authority as representatives of the Catholic Church.

The changing character of the ritual reflected the reforms initiated by the Second Vatican Council (1962-65). A key change involved the language of the Mass. Latin had been used for centuries in this prime liturgical celebration and since many worshippers could not understand this ancient language two modes of devotion had emerged - the priest conducting the Mass with his back to the congregation and many within the congregation pursuing their own devotions such as reciting the rosary. To close this ritual gap between the clerical 
leadership and lay worshippers more and more elements of the Mass were communicated through national languages. At Lourdes this led to the increasing use of vernacular languages for the prayers, invocations and hymns performed during the Blessed Sacrament ceremony with Latin only being used in the Salve Regina hymn at the end of the ceremony. Yet, the ritual still seemed to emphasise the Church's authority over the passive, disciplined body; the active agents were the officials - priests, members of the Hospitality and those in the procession looking on, especially the doctors - led by the cardinal or bishop wielding the Host in its glittering, golden monstrance.

When I returned in 2013 after a twenty one year break the ceremony had been radically changed. It began opposite the grotto around a large altar and a long procession wound its way across the river, up to one of the main gates and down to the massive underground basilica leaving the esplanade empty. 'Malades' formed an integral part of the procession and their helpers stayed with them throughout the journey. The 'malades' were far less passive objects of an official gaze and their agency was vividly expressed through their use of cameras, mobile phones and ipads to record the Blessing of the Sick. Yet, despite the greater mobility and increased agency of the lay participants the fundamental character of the ceremony remained - the climax of the ceremony was still the arrival of the clergy with the senior celebrant blessing the congregation with the Host in its golden monstrance.

\section{The British Pilgrimage Trust and the invention of place, routes and rituals}

The growing popularity of walking and walking tours during the last fifty years in Britain and other European countries has encouraged the revival of mediaeval pilgrimage routes such as those leading to Santiago de Compostela, Catholic shrines in France and Italy as well as to cathedrals, former monasteries and other sacred places across Britain. As the burgeoning literature on pilgrimage tourism and religious tourism has shown, many walkers are not 
involved in institutional religion and express a wide variety of reasons for travelling along these ancient routes and new routes.

The British Pilgrimage Trust illustrates this dynamic situation very clearly. Since its foundation in 2005 it has developed courses and walking tours through the resourceful use of social and mass media and by building networks between official bodies such as English Heritage and the Church of England. In a 2006 article, 'Pilgrimages are back with less Christianity', by the deputy editor of a Catholic weekly, the founders clearly articulated their approach:

The BPT stresses that not all pilgrims are religious: 'Bring your own beliefs' is the slogan. Guy Hayward, who co-founded the BPT with Will Parsons, observes: 'We have to tread very carefully around the language of spirituality and religion.' But he thinks pilgrimage has a universal appeal: it connects you to the world, and to other people. 'You're walking in the land, in nature, you're talking to people. It's not complicated, but at the same time it's very tangible.'

Perhaps, then, pilgrims should leave their smartphones at home? 'No, no!' Parsons is emphatic. 'We think that modern pilgrimage requires modern technology to make the most of it.' Phone maps are better than a fold-out when you're lost in a wood. The BPT plans an app to link pilgrims with accommodation spots — churches, fields, village halls. https://www.spectator.co.uk/2016/07/pilgrimages-are-back-with-less-christianity/ 
This was the background to a pilgrimage/walking tour I undertook on February 2, 2020. The eleven mile circular walk was booked online and its prime destination was Avebury, a village in south-west England, and the Avebury Henge and Stone Circles, a UNESCO World Heritage site. According to English Heritage:

Built and much altered during the Neolithic period, roughly between $2850 \mathrm{BC}$ and $2200 \mathrm{BC}$, the henge survives as a huge circular bank and ditch, encircling an area that includes part of Avebury village. Within the henge is the largest stone circle in Britain - originally of about 100 stones - which in turn encloses two smaller stone circles.

https://www.english-heritage.org.uk/visit/places/avebury/

As English Heritage proceeds to explain, Avebury 'is part of an extraordinary set of Neolithic and Bronze Age ceremonial sites that seemingly formed a vast sacred landscape'. These sites 'include West Kennet Avenue, West Kennet Long Barrow, The Sanctuary, Windmill Hill, and the mysterious Silbury Hill' (Ibid) and this World Heritage landscape extended to the more famous Stonehenge only forty five minutes away by car. Avebury attracted those who wanted to explore beyond the country's Christian heritage and the walk provided a vivid insight into the invention of rituals that contrasted sharply with those performed at Lourdes.

Guy Hayward, the co-founder of the BPT, sent instructions about where to meet by email and the walk began at the village of East Kennet. Twenty five participants assembled in the village church where Guy and his two colleagues, Chris and Charlotte, greeted us and explained the significance of the day. In the Christian tradition it was Candlemas, which commemorated the presentation of Jesus at the temple in Jerusalem, and the Church of England's celebration involved the blessing of candles brought by worshippers who would use them throughout the year as a memento. However, Chris and Charlotte chose to emphasise the pre-Christian origins of the festival. Chris was a member of the Order of 
Bards, Ovates and Druids, a story teller, ecological artists and bee keeper, who lived not far away $^{\mathrm{i}}$, while Charlotte ran a business in London as a modern day alchemist, natural health practitioner, pilgrimage ceremonialist and ritual facilitator and provided an online apothecary. ${ }^{\text {ii }}$

Chris referred to the goddess Brighid, whose wooden cross he was holding, and explained that she was associated with Imbolc, the festival of light and fire that celebrated the half way point between the winter and spring solstice and the beginning of a new year as days start to lengthen. He gave everyone a blunt pin to which we could attach our hopes and prayers for what we wanted from the day and later place it in the River Kennet. He also explained about the development of agriculture, settled populations and religious experts. Charlotte then spoke about Brighid as goddess of fertility with her close link to Ireland, her many names (Bree, Britannia, Brigid, Brich). Guy finished this introduction by talking about the church, the nearby River Kennet and the importance of water. He then sang a song (he was a former Cambridge University choral scholar) about our relationship to nature and explained where we were walking to.

As we walked to the next stop - a Neolithic stone circle - I was able to take stock of the group and get to know some of them. Most appeared to be white middle class professionals between the ages of 40 to 65,17 of the 25 were women, and judging by people's attire many were experienced walkers. They included two travel writers, a journalist who was going to write an article on the day for The Guardian newspaper ${ }^{\mathrm{iii}}$, an IT project manager, a researcher, a retired businessman, a local farmer, several small business entrepreneurs including the BPT organisers (Guy, Charlotte and Chris), a American regular visitor to Britain and a duchess who was one of the BPT's trustees. Since I was only able to talk to a few in the group I was unable to learn much about the participants' beliefs 
concerning pilgrimage but clearly they were open to the inclusive approach adopted by the group leaders even if some had come from conventional religious backgrounds (one was a clergyman's daughter, another was a regular Anglican worshipper, while another was a Muslim convert).

At each Neolithic site the leaders had devised a small ritual to help people connect with one another and with the place itself. At the first stop on the walk, after everyone had looked at the signs provided by English Heritage that explained the site's history and slowly walked round the outer ring of stones, we formed a circle in the centre. Guy explained the site's history and reminded us to think about our intentions for undertaking the pilgrimage while Chris blessed a nearby stone with mead he had brewed himself from a small glass jar. As the wind and rain blew across the open landscape he asked us in turn to pronounce our first names and then look carefully at each member of the group. At the end of this ritual he explained that names bore the essence of a person or thing.

The weather improved as we made our way to the Long Barrow where once again Chris outlined the history of the place and the surrounding landscape. He explained that the entrance, marked by a massive stone, faced east to the rising sun, birth, heat, life in contrast to the west where the sun sets. He encouraged people to go inside and hum like the bees to evoke the spooky atmosphere, while Charlotte suggested that we commune with the stone by pressing our foreheads against it, bringing our prayers, petitions and blessings.

The third place we visited was the most interesting in its rich symbolism. We walked across fields and down to a spring linking to the Kennet. Chris explained the significance of springs and wells, Charlotte again referred to Brighid and asked us to pronounce her names and encouraged us to wash in the water, even ford it on the stepping stones, Guy had a water filter which he used to let people drink from a bottle and about five people did this. There 
was also a weeping willow tree near the junction of the riverlet and the main stream and Charlotte explained the meanings associated with this tree. There were many ribbons on another willow tree by the riverlet where people drank from the filtered water and Guy sang the song about nature with Charlotte, Chris and several others in the group. The sacred quality of the site was, however, spoiled for some by the black plastic covers and rubbish left by other 'pilgrims' in the nearby undergrowth.

The rest of pilgrimage became more like a walk. People were getting tired as we had to negotiate a steep ascent to the next site - a burial ground on the outskirts of the Avebury complex - where we rested and had a picnic. We then walked down to Avebury itself where the pilgrimage neatly brought together pre-Christian and Christian heritage as we walked round the famous stone circle (henge) and visited the parish church with its rare surviving rood screen. The henge was constructed between 2850 and 2220 BCE and originally comprised:

a huge circular earthwork mound and ditch that surrounds the inner stone circle. The circle consisted of large sarsen stones, some as large as 40 tonnes and a height of over 4 meters, and originally it had around 100 stones in total. This outer circle then encased a further two inner circles. https://lostinlandmarks.com/guide-to-visiting-avebury-stone-circle-village-wiltshire/ It was abandoned after $1800 \mathrm{BCE}$ and a village gradually developed with the inhabitants making use of the abandoned stones.

almost all of the large sarsen stones have been removed in previous centuries by locals for either religious reasons (many were destroyed in the 17th and 18th century 
when Puritans were more mainstream in the country and also in the 14th century as is seen with the discovery of a body under a buried stone) or for building materials. (Ibid)

A busy road now runs through the henge as it leads up to the motorway between London and Bristol.

The members of the group were invited to perform two rituals that referred to Avebury's pre-Christian and Christian heritage. When we arrived at the henge Guy talked about its history and then invited people to commune with its history and material energy by sitting on a seat carved into one of the remaining huge stones on the outer ring. A few solemnly proceeded to do so while others walked over to the rampart circling the henge and the 'Tolkien trees' with their profuse, exposed, snake-like roots, festoon of ribbons and messages left on their trunks. ${ }^{\text {iv }}$ After crossing the busy road and a toilet break, Guy led us to the village church, stopping at the lynch gate which he described in terms of the Christian break with pre-Christian traditions. While the sacred was immanent everywhere before Christianity, the gate was a liminal space marking the transition from the secular world into the sacred space of the church and its surrounds. In the apex of the gate's lintel was careved a scallop shell - a reminder of famous Christian pilgrimage this out, a scallop shell was carved into the apex of the gate's lintel - a reference to the church's dedication to St James the Apostle and a link to another pilgrimage route, the camino, leading to St. James's shrine at Santiago de Compostela. After browsing around the church which seemed very welcoming to this eclectic range of visitors/pilgrims, the group made their way as night fell back to their cars, completing the circular tour, and group solidarity quickly broke down as tired limbs and minds encouraged people to make a quick get-away.

\section{Discussion}


I have brought together here two case studies of how rituals are invented and deployed, drawing on my personal experience. While my involvement with pilgrimage to Lourdes has been far more extensive and long term than connection with the British Pilgrimage Trust (the lockdown following the outbreak of Covid 19 in Britain put an end to subsequent trips), I believe that there is sufficient material here for comparison and a more general discussion.

\section{Creating sacred places and rituals: institutions and entrepreneurs}

The case studies illustrate the role played by institutions and entrepreneurs in establishing the sacrality of particular places and inventing the rituals at these places. The emerging cult at Lourdes was developed by the Roman Catholic Church whose religious leaders drew on a rich heritage of meaning-making through ritual. The grotto where Bernadette experienced her visions was sacralised by the ceremonies held there, the erection of an altar and a massive candle tree, and the channelling of the spring. The long-established tradition of processing and blessing worshippers was utilised to create the Blessing of the Sick ceremony performed in a new sacred space - the Esplanade - flanked by altars and overlooked by statues of renowned saints.

As for the Avebury pilgrimage the rituals were invented by members of a very different institution and referred to a very different past. The British Pilgrimage Trust was a recent network of young entrepreneurs who took a highly eclectic approach towards pilgrimage and the past, drew on the interest in walking to devise a variety of walks and revive historic routes and sought to take advantage of virtual communication through the internet and mobile phones. The practices devised by the three leaders for the February walk were influenced by 'New Age' beliefs and were designed to celebrate the sacrality of a preChristian social and material world. Although the day began and drew to a close at two 
village churches, the focus was on the sacred sites of a Neolithic landscape and pre-Christian heritage.

The invention of ritual and the creation of sacred space raise the issue of authority. At Lourdes Bernadette explained her visions to a sceptical parish priest and it was only after a detailed investigation by the local bishop that the full weight of the institutional church swung behind the emerging cult. The ceremonies introduced at the sanctuary were devised and controlled by the clergy, even if their performance was assisted by the lay volunteers who worked for the confraternities. In other words, authority was primarily vested in the ascribed status of Church officials. Members of the Hospitality could achieve authority and wield limited power over others through long service and progress to the higher reaches of the confraternity's hierarchical structure but overall authority within the sanctuary was exercised by representatives of the Church Universal.

Like members of the Lourdes Hospitality, those leading the Avebury pilgrimage relied on their achieved status within the British Pilgrimage Trust as experts on heritage and folklore and as performers. Guy, for example, drew not only on his wide range of reading about pilgrimage but also on his choral training and experience of performing musical comedy. The BPT was a loose coalition of different interests and people that depended on a variety of events and worked with more permanent institutions, particularly the Church of England and English Heritage. Its development relied heavily on the enthusiasm of a few dedicated members, who survived financially through their entrepreneurial skills and connections.

$\underline{\text { Ritual and the relationship between people and the landscape }}$

The case studies provide strikingly different illustrations of the relationship between people and the landscape. At Lourdes Bernadette's visions occurred at a place outside the town 
which was associated with dangerous spirits and the Church moved quickly to domesticate the grotto and the surrounding landscape. The erection of a gothic style basilica on top of the cliff overlooking the grotto was a reminder to visitors of the Church's presence and power. By the end of the nineteenth century sacred space had been created behind the two main gates and the surrounding walls that contained the grotto, the baths and medical bureau, a hostel for the 'malades', the esplanade and the processional avenues and the three churches rising up to the crown of the cliff. During the 1950s the building works within the sanctuary began again with the construction of the massive underground church, while later building works have extended across the river in the meadow with the construction of a hospital, conference centre and chapel, a large altar, a youth centre and an easy access Stations of the Cross which complemented the old hilly Stations of the Cross overlooking the sanctuary.

At first sight the landscape encountered during the walk to Avebury and the rituals performed there appeared to be very different. In contrast to the bustling town of Lourdes and its busy sanctuary, the route took us across empty fields, up to wind-swept hills, down to a winding river surrounded by trees and along an avenue flanked by ancient stones to the Avebury henge itself. Although Avebury was a village with shops, pub, church and busy road, the journey was devoid of other people and we were continually reminded of our relationship with nature. The rituals devised by the leaders encouraged us to engage with the immanent energy and power of material things, such as the massive stones, the spring and river, the trees and their snaking roots. Many of the participants clearly enjoyed touching and feeling the stones, listening to the sound of their voices humming inside the long barrow, drinking the water from the stream and sitting inside the massive stone at the Avebury henge. Ours was a sensual experience in other words and was similar to the walks described by Maddrell and others. 
The rituals were inspired by 'New Age' or alternative spiritual beliefs and practices. These were most evident during Chris's blessing of the stones at the Sanctuary, the rituals performed by Guy and Charlotte at the spring, the references to the energy of the landscape's ley lines, to the goddess Brighid and the festival of Imbolc. Yet, although the leaders acted as guides to the route and the sacred places, initiating kinetic rituals and referring to the magnetic power of the landscape and imparted specific knowledge about heritage and preChristian beliefs and practices, many participants appeared to draw on their own stocks of knowledge and performed their own rituals (see Coleman, Mesaritou and Eade 2015; Mesaritou, Coleman and Eade 2020).

Yet, care needs to be taken not to overemphasise the differences between the two pilgrimages and fit them within a religious/spiritual pilgrimage binary. In both cases rituals had been invented and (at Lourdes) reinvented through the entrepreneurship of leaders versed in particular knowledges. The rituals were designed to engage the senses and to heighten the emotional engagement with others - not just other humans but more-than-human others such as the Host and saints at Lourdes and the stones, spring and trees during the BPT pilgrimage. If the landscape at Lourdes has been highly domesticated, the fields, hills and woods across which we walked towards Avebury had also been domesticated through intensive agriculture and other forms of human ordering. In both cases we see the increasing agency of the ritual participants, who brought their own knowledges, questions and consumer items to record their experiences, i.e. cameras, smart phones and ipads.

\section{Conclusion}

In this article I have explored the ways in which rituals have been invented and adapted over time in the context of pilgrimage to different types of sacred site. The two case studies reveal, not surprisingly, significant differences in ritual discourse and practice but also similarities 
which challenge conventional typologies. The comparison revealed two key themes - (a) the role of institutions and entrepreneurs in creating rituals and sacred places and (b) the relationship between people and the domesticated landscape.

Ritual studies has demonstrated the manifold ways in which particular ritual discourses and practices both shape and are shaped by wider social, political and economic processes. The case studies show that the participants possess their own agency and power which is expressed through the growth of consumerism and leisure, alternative forms of knowledge, the questioning of traditional expertise, and increased mobility (see Urry 1995 , 2000, Pink 2016). Institutions such as the Roman Catholic Church have sought to respond to these general developments expressed in the decline across W. Europe of congregational worship by seeking to draw the millions visiting shrines across Europe into Church ritual. An alliance is sought between the territorial model of parish and diocese and the mobilities integral to pilgrimage (see Eade 2017). The BPT also seeks to draw on the territorial model of parish and diocese - in this case, the Church of England - but its ritual discourse and practices reflect even more the mobilities, flows and mixture of elements characterising the wider changes taking place across $\mathrm{W}$. Europe during the last fifty years.

\section{References}

Abélès, Marc. 1988. Modern Political Ritual: Ethnography of an Inauguration and a Pilgrimage by President Mitterrand. Current Anthropology 29 (3): 391-404. Badone, Ellen and Sharon Roseman eds. 2004. Intersecting Journeys: The Anthropology of Pilgrimage and Tourism. Urbana and Chicago: University of Illinois Press. Bajc, Vijda. 2007. Creating Ritual through Narrative, Place and Performance in Evangelical 
Bar, Doron and Kobi. Cohen-Hattab. 2003. A New Kind of Pilgrimage: The Modern Tourist Pilgrim of Nineteenth Century and Early Twentieth Century Palestine. Middle Eastern Studies 39 (2): 131-148.

Bowman, Marion. 1993. Drawn to Glastonbury. Pilgrimage in Popular Culture. Edited by Ian Reader and Tony Walter. Basingstoke: Macmillan, pp. 29-62

Coleman, Simon and John Eade eds. 2004. Reframing Pilgrimage: Cultures in Motion. New York and London: Routledge.

Collins-Kreiner, Noga. 2010. Researching Pilgrimage: Continuity and Transformations. Annals of Tourism Research 37 (2): 440-456.

Collins-Kreiner, Noga. 2016. The Lifecycle of Concepts: The Case of "Pilgrimage Tourism". Tourism Geographies 18 (3): 322-334.

Collins-Kreiner, Noga and Nurit Kliot. 2000. Pilgrimage Tourism in the Holy Land: The Behavioural Characteristics of Christian Pilgrims. GeoJournal 50: 55-67.

Dahlberg, Andrea. 1991. The Body as a Principle of Holism: Three Pilgrimages to Lourdes. Contesting the Sacred: The Anthropology of Christian Pilgrimage. Edited by John Eade and Michael Sallnow. London and New York: Routledge, pp. 30-50.

Eade, John. 1992. Pilgrimage and Tourism at Lourdes, France. Annals of Tourism Research 19 (1): $18-32$.

Eade, John. 2017. Parish and Pilgrimage in a Changing Europe. Migration, Transnationalism and Catholicism: Global Perspectives. Edited by Dominic Pasura and Marta Bivand 
Erdal. Basingstoke UK: Palgrave Macmillan, pp. 75-92.

Eade, John and Mario Katic eds. 2014. Pilgrimage, Politics and Place-Making in Eastern Europe. Farnham, UK: Ashgate.

Fedele, Anna. 2013. Looking for Mary Magdalene: Alternative Pilgrimage and Ritual Creativity at Catholic Shrines in France. Oxford and New York: Oxford University Press.

Feldman, Jacky. 2007. Constructing a Shared Bible Land: Jewish Israeli Guiding Performances for Protestant Pilgrims. American Ethnologist 34 (2): 351-374.

Feldman, Jacky. 2008. Israeli Youth Voyages to Holocaust Poland: Through the Prism of Pilgrimage. Redefining Pilgrimage: New Perspectives on Historical and Contemporary Pilgrimages. Edited by Anton Pazos. Farnham UK and Burlington VT: Ashgate, pp. 87-102.

Frey, Nancy. 1998. Pilgrim Stories: On and Off the Road to Santiago. Berkeley and Los Angeles: University of California Press.

Grimes, Ronald. 1992. Reinventing Ritual. Soundings 75 (1), pp. 21-41.

Harris, Ruth. 1999. Lourdes: Body and Spirit in the Secular Age. London and New York: Allen Lane.

Ivakhiv, Adrian. 2001. Claiming Sacred Ground: Pilgrims and Politics at Glastonbury and Sedona. Bloomington, IN: Indiana University Press.

Karant-Nunn, S. 1997. The Reformation of Ritual: An Interpretation of Early Modern Germany, London and New York: Routledge. 
Kaufman, Susanne. 2005. Consuming Visions: Mass Culture and the Lourdes Shrine. Ithaca And London: Cornell University Press.

King, Christine. 1993. His Truth Goes Marching On: Elvis Presley and the Pilgrimage to Graceland. In Pilgrimage in Popular Culture, Edited by Ian Reader and Tony Walter. Basingstoke: Macmillan, pp. 92-106.

Kormina, Jeanne. 2010. Avtobusniki: Russian Orthodox Pilgrim's Longing for Authenticity. In Orthodoxy, Orthopraxy, Parádosis: Eastern Christians in Anthropological Perspective. Edited by Chris Hann and H. Goltz. Berkeley: University of California Press, pp. 267-286.

Lopez, Lucrezia. 2013. How Long Does the Pilgrimage Tourism Experience to Santiago de Compostela Last? International Journal of Religious Tourism and Pilgrimage, $1(1)$, pp. 1-14.

Maddrell, Avril, Veronica della Dora, Alessandro Scafi and Heather Walton. 2015. Christian Pilgrimage, Landscape and Heritage: Journeying to the Sacred. New York and Abingdon UK: Routledge.

Mantsinen, Teemu. 2020. Pilgrimage as a Reproduction of Sacred Landscape in Finnish Karelia and the Russian Border Zone. Temenos: Nordic Journal of Comparative Religion 56 (1), pp. 7-31.

Margry, Peter Jan. 2008. The Pilgrimage to Jim Morrison's Grave at Père Lachaise Cemetery: The Social Construction of Sacred Space. In Shrines and Pilgrimage 
in the Modern World: New Itineraries into the Sacred. Edited by Peter Jan Margry.

Amsterdam: Amsterdam University Press, pp. 143-172.

Mesaritou, Evgenia, Simon Coleman and John Eade. 2015. Introduction: Guiding the Pilgrim. Tourist Studies 16 (1), pp. 1-20.

Mesaritou, Evgenia, Simon Coleman and John Eade. 2020. Introduction. Knowledge, Ignorance, and Pilgrimage. Journeys 21 (1), pp. 1-18.

Nolan, Mary and Stanley Nolan. 1989. Christian Pilgrimage in Modern Western Europe. Chapel Hill, NC, and London: University of N. Carolina.

O'Brien, Suzanne Crawford. 2008. Talking Place: Ritual and Reciprocity at Holy Wells and Mass Stones in the Republic of Ireland. Journal of Ritual Studies 22 (1), pp. 120.

Pink, Sarah. 2016. Photographic Places and Digital Wayfaring: Conceptualizing Relations between Camera, Connectivities, and Transformed Localities. In Digital Photography and Everyday Life: Empirical Studies on Material Visual Practices. Edited by Edgar Gomez Cruz and Asko Lehmuskallio. New York and London: Routledge, pp. 186190.

Reader, Ian. 2014. Pilgrimage in the Marketplace. New York and London: Routledge.

Rountree, Kathryn. 2006. Performing the Divine: Neo-Pagan Pilgrimages and Embodiment at Sacred Sites, Body \& Society 12 (4), pp. 95-115.

Sanchez y Sanchez, Samuel and Annie Hesp. 2006. The Camino de Santiago in the 21st Century: Interdisciplinary Perspectives and Global Views. New York and Abingdon, 
UK: Routledge.

Schramm, Katharina. 2004. Coming Home to the Motherland. In Reframing Pilgrimage:

Cultures in Motion. Edited by Simon Coleman and John Eade. London and New

York: Routledge, pp. 133-149.

Shuo, Yea Shi, Cris Ryan and Ge Liu. 2009. Taoism, Temples and Tourists: The Case of

Mazu Pilgrimage Tourism. Tourism Management 30 (4), pp. 581-588.

Steil, Carlos. 2017. Studies of Catholicism and Pilgrimage in Brazil: Continuities and

Ruptures over the Long Term. In New Pathways in Pilgrimage Studies: Global

Perspectives. Edited by Dionigi Albera and John Eade. New York and Abingdon,

UK: Routledge, pp. 162-180.

Stern, Nehemia. 2012. Hitchhiking and Ritual Ambiguity of Jewish Settlers in the West Bank. Ethnology 51 (1-2), pp. 75-92.

Tweed, Thomas. 2006. Crossing and Dwelling: A Theory of Religion. Cambridge Mass. and London: Harvard University Press.

Urry, John. 1995. Consuming Places. London and New York: Routledge.

----- Sociology Beyond Societies: Mobilities for the Twenty-First Ccentury., London and New York: Routledge.

Vukonic, Boris. 2002. Religion, Tourism and Economics: A Convenient Symbiosis. Tourism Recreation Research 27 (2), pp. 59-64.

Walter, Tony. 1993. War Grave Pilgrimage. In Pilgrimage in Popular Culture. Edited by Ian Reader and Tony Walter. Basingstoke UK: Macmillan, pp. 63-91. 
Wikan, Unni. 1990. Managing Turbulent Hearts: A Balinese Formula for Living. Urbana and Chicago: University of Chicago Press.

Zola, Ēmile. 1995 [1894). Lourdes, Paris, Folio.

\footnotetext{
i https://www.wisdomkeepers.earth/post/interview-with-chris-park

ii see https://www.instagram.com/pulvers.apothecary/?hl=en.
}

iii The article was published on February 29 by Holly Tuppen, 'Stone circles, silence and sanctuary: finding yourself on an Avebury pilgrimage', https://www.theguardian.com/travel/2020/feb/19/stone-circles-silence-sanctuary-aveburypilgrimage-silbury-hill, accessed 23/7/2020.

iv In a blog, written by a 'twenty-something traveler, occasional female solo traveler', the trees were associated with Tolkien's Lord of the Rings: 'My friend, who had been before, told me these trees had been the inspiration for JRR Tolkien's 'walking trees' or Ents in The Lord of the Rings. If you've either seen the film or read the books, you'll recall the walking trees I'm talking about ... Ents are the huge talking trees that help the hobbits. People have tied ribbons to the tree's branches with wishes written on them. Unfortunately, I didn't know this was also the Avebury wishing tree, so I didn't have a ribbon on me'.

https://www.travelherstory.com/europe/visit-jrr-tolkiens-trees-avebury 